\title{
Demam Berdarah Dengue di Perdesaan
}

\author{
Dengue Hemorraghic Fever in Rural
}

\author{
Erna Kusumawardani, Umar Fahmi Achmadi
}

\section{Departemen Kesehatan Lingkungan Fakultas Kesehatan Masyarakat Universitas Indonesia}

\begin{abstract}
Abstrak
Berbeda dengan beberapa negara, laporan kejadian kasus demam berdarah dengue (DBD) di perdesaan Indonesia belum banyak dilaporkan. Penelitian ini bertujuan untuk memberikan gambaran kejadian DBD di perdesaan di wilayah perbatasan Kabupaten Bogor dan Kabupaten Lebak, Jawa Barat. Penelitian ini menggunakan desain studi kasus seri dengan sampel seluruh penderita DBD yang tercatat di puskesmas pada periode bulan Januari 2011 sampai April 2012. Hasil penelitian menemukan 18 kasus DBD dan 4 kasus kematian (case fatality rate, CFR $=22 \%$ ). Sebagian besar kasus berjenis kelamin laki-laki $(58,3 \%)$, berusia $\geq 15$ tahun $(58,3 \%)$, tidak bekerja/ibu rumah tangga (50\%), melakukan mobilitas (66,7\%), mempunyai pengetahuan yang baik $(66,7 \%)$, berperilaku kurang baik $(83,3 \%)$, dan mempunyai tempat penampungan air (100\%). Lima dari 12 kasus DBD $(41,7 \%)$ diduga merupakan kasus lokal. Dari empat puskesmas $(57,1 \%)$ yang melakukan kegiatan penyelidikan epidemiologi DBD terindikasi bahwa kemungkinan besar telah terjadi transmisi DBD di wilayah perdesaan daerah perbatasan Kabupaten Bogor dan Kabupaten Lebak.

Kata kunci: Demam berdarah dengue, perdesaan, transmisi
\end{abstract}

\begin{abstract}
Dengue hemorrhagic fever (DHF) has long been reported as disease affecting predominantly among urban populations. However, several recent studies suggest that DHF has spread into rural area. This study aims to describe disease occurrence of DHF in border rural areas of Bogor - Lebak. The study design is case series. The sample of this study was all patients with confirmed DHF admitted to public health centers between January 2011 and April 2012. The study was conducted in April to May 2012. The results showed that there were $19 \mathrm{DHF}$ cases and four out of 18 cases died (case fatality rate, CFR was $22 \%$ ). Out of 12 eligible respondents, most of them were male $(58,3 \%)$, aged $\geq 15$ years $(58,3 \%)$, unemployed/housewife (50\%), conducting mobility $(66,7 \%)$, having good knowledge $(66,7 \%)$, behave poorly $(83,3 \%)$, and having water containers (100\%). Five of $12 \mathrm{DHF}$
\end{abstract}

cases $(41,7 \%)$ were suspected as local cases. Four primary health centers $(57,1 \%)$ were able to perform PE DBD (DHF Epidemiological Investigation). These results indicate that the transmission of DHF in border rural areas of Bogor - Lebak, most likely has occurred.

Key words: Dengue hemorrhagic fever, rural, transmission

\section{Pendahuluan}

Beberapa dekade terakhir, insiden kasus penyakit yang disebabkan oleh virus dengue telah meningkat secara dramatis. Lebih dari 2,5 milyar orang atau sekitar $40 \%$ dari penduduk di seluruh belahan dunia berisiko menderita penyakit tersebut. World Health Organization (WHO) memperkirakan di seluruh dunia, sekitar 50 100 juta orang terinfeksi virus dengue setiap tahun. ${ }^{1}$ Sejak tahun 1950-an, demam dengue (DD) dan demam berdarah dengue (DBD) dilaporkan sebagai penyakit yang menyerang penduduk di wilayah perkotaan. ${ }^{2-5}$ Namun, beberapa penelitian akhir-akhir ini menunjukkan bahwa penyakit tersebut menyebar dari wilayah kota besar yang berperan sebagai reservoir virus ke berbagai wilayah permukiman masyarakat yang lebih kecil. ${ }^{2}$

Di Indonesia, sampai saat ini, DBD masih menjadi salah satu masalah kesehatan masyarakat utama. ${ }^{6}$ DBD merupakan salah satu penyakit endemis perkotaan. Sejak pertama kali ditemukan pada tahun 1968 di wilayah Surabaya dan Jakarta, jumlah kasus DBD terus meningkat dalam jumlah dan luas wilayah yang terjangkiti. Setiap tahun, secara sporadis selalu terjadi kejadian

Alamat Korespondensi: Erna Kusumawardani, Departemen Kesehatan Lingkungan Gd. C Lt. 2 FKM Universitas Indonesia, Kampus Baru UI Depok 16424, Hp.085649697495, e-mail: kusumawardani.erna@gmail.com 
luar biasa (KLB)..$^{7,8}$

Mobilitas penduduk merupakan salah satu mekanisme yang berkontribusi pada kejadian penyakit melalui penyebaran virus dengue. ${ }^{2}$ Menghadapi mobilitas penduduk yang tinggi, diperlukan kerja sama upaya pengendalian penyakit antarwilayah. Kabupaten/kota yang berbatasan wilayah dan mempunyai ekosistem penyakit yang sama wajib bekerja sama untuk menemukan dan mengobati penderita penyakit secara aktif serta mengendalikan faktor risiko penyakit. Hal tersebut dilakukan dalam perspektif ekosistem dan dinamika faktor risiko antarkabupaten/kota dan antarprovinsi. ${ }^{9}$

Kabupaten Bogor, Provinsi Jawa Barat dan Kabupaten Lebak, Provinsi Banten mempunyai daerah perbatasan langsung. Kedua kabupaten tersebut mempunyai ekosistem dan karakteristik yang sama untuk setiap masalah penyakit menular dan KLB. Secara khusus, kasus penyakit DBD masih menduduki peringkat teratas dalam vector borne disease. ${ }^{10}$ Berdasarkan data surveilans Kabupaten Bogor dan Kabupaten Lebak, didapatkan data bahwa kejadian DBD merupakan penyakit prioritas di daerah perbatasan kedua kabupaten tersebut, tepatnya di Kecamatan Tenjo, Jasinga, Sukajaya, Maja, Curugbitung, Cipanas, dan Lebak Gedong. 10

Tujuan penelitian ini adalah mengetahui karakteristik kejadian DBD di wilayah perdesaan daerah perbatasan Kabupaten Bogor dan Kabupaten Lebak tahun 2012 karena kejadian DBD di wilayah perdesaan masih belum banyak dipelajari dan dilaporkan, terutama tentang karakteristik penderita dan potensi penularan horizontal DBD di wilayah perdesaan tersebut.

\section{Metode}

Desain penelitian yang digunakan oleh peneliti adalah desain serial kasus untuk menggambarkan variabel orang, tempat, dan waktu pada sekelompok orang yang menderita penyakit. Penelitian ini dilaksanakan di Kecamatan Tenjo yang terletak di daerah perbatasan Kabupaten Bogor dan Kabupaten Lebak, Jasinga, dan Sukajaya (Kabupaten Bogor), serta Kecamatan Maja, Curugbitung, Cipanas, dan Lebak Gedong (Kabupaten Lebak). Penelitian dilaksanakan pada periode akhir bulan April sampai Mei 2012. Populasi penelitian adalah semua kasus confirm DBD yang dilaporkan ke Puskesmas Tenjo, Jasinga, Sukajaya, Maja, Curugbitung, Cipanas, dan Lebak Gedong. Sampel penelitian adalah seluruh kasus confirm DBD yang memiliki catatan rekam medis lengkap di tujuh puskesmas tersebut. Data yang diambil adalah data kejadian DBD, karakteristik penderita DBD, potensi penularan horizontal, dan kegiatan penyelidikan epidemiologi DBD yang dilakukan oleh puskesmas di wilayah perdesaan daerah perbatasan Kabupaten Bogor dan Kabupaten Lebak dari tahun 2011 sampai tahun 2012.
Data karakteristik penderita DBD yang dikumpulkan meliputi jenis kelamin, usia, pekerjaan, mobilitas, pengetahuan tentang DBD, perilaku pencegahan DBD, dan tempat penampungan air (TPA) yang ada di rumah penderita. Data potensi penularan horizontal DBD yang dilihat dari riwayat penyakit dan mobilitas didapatkan melalui wawancara dan observasi menggunakan instrumen kuesioner. Data kejadian DBD dan kegiatan penyelidikan epidemiologi DBD didapatkan melalui observasi data di puskesmas dan wawancara langsung dengan petugas puskesmas. Jika responden masih anak-anak atau berusia di bawah 15 tahun dan/atau tercatat sebagai kasus kematian DBD, wawancara dilakukan pada anggota keluarga yang berusia 15 - 60 tahun.

\section{Hasil}

Distribusi kejadian DBD di tiap kecamatan di daerah perbatasan menunjukkan jumlah kasus terbesar terdapat di Kecamatan Maja (7; 38,9\%) dan terkecil di Kecamatan Curugbitung dan Tenjo (0; 0\%). Jumlah kasus meninggal terbanyak adalah Kecamatan Sukajaya Lebak Gedong dan terkecil Kecamatan Jasinga (0\%).

Case fatality rate (CFR) DBD di daerah penelitian tersebut adalah $22 \%$, sementara menurut Kementerian Kesehatan Republik Indonesia, target nasional CFR DBD adalah di bawah 1\%.7 Dari 18 kasus DBD yang ada di setiap wilayah penelitian pada periode 1 Januari 2011 hingga April 2012, hanya 12 responden yang bersedia disertakan dalam penelitian ini (Tabel 1).

Sebagian besar responden berjenis kelamin laki-laki $(58,3 \%)$, berusia $\geq 15$ tahun $(58,3 \%)$, tidak bekerja/ibu rumah tangga (IRT) $(50 \%)$, melakukan mobilitas $(66,7 \%)$, memiliki pengetahuan yang baik $(66,7 \%)$, berperilaku kurang baik $(83,3 \%)$, dan semua responden (100\%) memiliki TPA (Tabel 2).

Potensi penularan horizontal DBD responden yang diduga merupakan kasus lokal kemungkinan besar diperoleh dari sumber penularan setempat wilayah perdesaan sejumlah 5 orang (42\%) (Gambar 1).

\section{Pembahasan}

Kejadian DBD di wilayah perdesaan daerah perbatasan Kabupaten Bogor dan Kabupaten Lebak tahun 2012 adalah 19 kasus. Beberapa penelitian yang dilakukan oleh Vong et al, ${ }^{11}$ Zafar et al, ${ }^{4}$ Azam, ${ }^{12}$ juga menjelaskan bahwa kejadian DBD telah terjadi di wilayah perdesaan. Penjelasan tentang penyebaran DBD ke wilayah perdesaan antara lain pekerja migran yang pulang ke desa karena menderita sakit DBD atau kemungkinan nyamuk Aedes sp. yang merupakan vektor DBD "terbawa" ke desa dan di desa menemukan tempat perindukan potensial. Konektivitas desa-kota serta perbaikan transportasi memungkinkan migrasi penderita viremia ke wilayah perdesaan dan terdapat riwayat inter- 
Tabel 1. Distribusi Kasus DBD Meninggal dan Sembuh Per Kecamatan

\begin{tabular}{|c|c|c|c|c|c|c|c|c|c|c|c|c|}
\hline \multirow{3}{*}{ Kasus } & \multicolumn{10}{|c|}{ Kecamatan } & & \\
\hline & \multicolumn{2}{|c|}{ Jasinga } & \multicolumn{2}{|c|}{ Sukajaya } & \multicolumn{2}{|c|}{ Maja } & \multicolumn{2}{|c|}{ Cipanas } & \multicolumn{2}{|c|}{ Lebak Gedong } & \multicolumn{2}{|c|}{ Jumlah } \\
\hline & $\mathbf{n}$ & $\%$ & $\mathbf{n}$ & $\%$ & n & $\%$ & $\mathbf{n}$ & $\%$ & n & $\%$ & $\mathbf{n}$ & $\%$ \\
\hline Meninggal & 0 & 0 & 1 & 100 & 1 & 14,3 & 1 & 20 & 1 & 50 & 4 & 22,2 \\
\hline Sembuh & 3 & 100 & 0 & 0 & 6 & 85,7 & 4 & 80 & 1 & 50 & 14 & 77,8 \\
\hline Jumlah & 3 & 100 & 1 & 100 & 7 & 100 & 5 & 100 & 2 & 100 & 18 & 100 \\
\hline
\end{tabular}

Tabel 2. Distribusi Karakteristik Responden

\begin{tabular}{llll}
\hline Variabel & Kategori & $\mathbf{n}$ & $\%$ \\
\hline Jenis kelamin & Laki-laki & 7 & 8,3 \\
Usia & Perempuan & 5 & 41,7 \\
& $\geq 15$ tahun & 7 & 58,3 \\
Pekerjaan & $<15$ tahun & 5 & 41,7 \\
& Petani & 0 & 0,0 \\
& Wiraswasta & 0 & 0,0 \\
Pekerjaan & Pegawai swasta & 4 & 33,3 \\
& PNS/TNI/Polri & 0 & 0,0 \\
Mobilitas & Tidak bekerja/IRT & 6 & 50,0 \\
& Lainnya & 2 & 16,7 \\
Pengetahuan & Ya & 8 & 66,7 \\
& Tidak & 4 & 33,3 \\
Perilaku & Kurang baik & 4 & 33,3 \\
& Baik & 8 & 66,6 \\
TPA & Kurang baik & 10 & 83,3 \\
& Baik & 2 & 16,7 \\
& Ada & 12 & 100,0 \\
& Tidak ada & 0 & 0,0 \\
\hline
\end{tabular}

aksi dengan vektor DBD ketika melakukan perjalanan desa-kota. 4,5,11,12

Berdasarkan keseluruhan kasus yang diamati, empat kasus ditemukan meninggal ( $\mathrm{CFR}=21 \%$ ) yang melampaui target nasional CFR DBD $(<1 \%)$. Hal tersebut kemungkinan besar terjadi karena kesulitan penduduk mengakses pelayanan kesehatan yang memadai dan keterlambatan atau kesalahan diagnosis sehingga penderita terlambat ditangani. Hal tersebut antara lain disebabkan oleh keadaan perekonomian penderita yang tergolong miskin dan kemampuan puskesmas menangani kasus DBD yang rendah.

Mengenai kaitan DBD dengan jenis kelamin, ditemukan pada beberapa penelitian lain bahwa sebagian besar penderita DBD berjenis kelamin laki-laki.13-16 Kemungkinan besar hal tersebut terjadi karena produksi cytokine pada perempuan lebih besar daripada laki-laki sehingga respon imun pada perempuan lebih baik daripada laki-laki. Selain itu, laki-laki lebih tertarik melakukan perjalanan ke luar daerah yang kemungkinan merupakan daerah endemis DBD. ${ }^{13,17}$ Kemungkinan lain adalah penduduk perdesaan yang mencari kerja ke perkotaan umumnya adalah laki-laki sehingga potensi tertular menjadi lebih besar.

Mengenai hubungan usia dengan DBD juga ditemukan oleh peneliti lain yang menjelaskan bahwa sebagian besar penderita DBD berusia $\geq 15$ tahun. ${ }^{16,18,19} \mathrm{Hal}$ tersebut kemungkinan besar karena penularan virus terjadi di berbagai lokasi tempat menghabiskan sebagian besar waktu di luar rumah, seperti di tempat kerja atau sekolah. Hal tersebut mengindikasikan lokasi terinfeksi virus Dengue telah berubah, tidak lagi di sekitar lingkungan rumah. ${ }^{20}$

Temuan tentang kaitan pekerjaan dengan DBD juga sesuai dengan hasil beberapa penelitian lain yang menjelaskan bahwa sebagian besar penderita DBD merupakan kelompok yang tidak bekerja atau ibu rumah tangga. ${ }^{21}$ Hal ini kemungkinan besar disebabkan orang yang tidak bekerja berpeluang berinteraksi dengan lingkungan yang cenderung lebih sempit daripada orang yang bekerja sehingga mempunyai pengetahuan yang relatif lebih rendah. Pengetahuan yang dimaksud berasal dari pengalaman pribadi dan orang lain. Pekerjaan juga berhubungan dengan penghasilan yang dapat digunakan untuk memelihara kesehatan melalui asupan makanan sehat dan bergizi yang diharapkan dapat meningkatkan daya tahan tubuh.

Temuan tentang kaitan variabel mobilitas dan DBD juga dilaporkan di beberapa penelitian lain yang menjelaskan bahwa sebagian besar penderita DBD melakukan mobilitas ke luar daerah. ${ }^{22-24}$ Kemungkinan besar hal tersebut terjadi karena kemajuan bidang transportasi yang meningkatkan mobilitas penduduk sehingga memudahkan penyebaran sumber penular DBD dari satu kota ke kota yang lain atau dari kota ke desa. Mobilitas penduduk yang tinggi tersebut disebabkan oleh lokasi pekerjaan, pencarian pelayanan kesehatan, belanja ke luar daerah, atau mengunjungi sanak keluarga.

Temuan tentang hubungan pengetahuan dengan DBD juga sesuai dengan temuan beberapa penelitian lain yang menjelaskan bahwa sebagian besar penderita DBD mempunyai pengetahuan yang baik tentang DBD. 21,25 Hal tersebut kemungkinan besar terjadi karena kesempatan mendapatkan informasi tentang DBD dari petugas kesehatan ketika penderita sedang menjalani pengobatan di 
Tabel 3. Hasil Kegiatan Penyelidikan Epidemiologi DBD oleh Petugas Puskesmas

\begin{tabular}{|c|c|c|c|c|}
\hline \multirow{3}{*}{ Kecamatan } & \multicolumn{3}{|c|}{ Penyelidikan Epidemiologi DBD } & \multirow{3}{*}{ Keterangan } \\
\hline & \multirow{2}{*}{$\frac{\text { Pelacakan Penderita/Tersangka DBD }}{\text { Positif }}$} & \multicolumn{2}{|c|}{ Pemeriksaan Larva/Jentik Nyamuk Aedes } & \\
\hline & & Positif & Negatif & \\
\hline Tenjo & - & - & - & Tidak ada PE \\
\hline Jasinga* $^{*}$ & - & $22 \%$ & $78 \%$ & Tidak ada PE \\
\hline Sukajaya & 0 & $54,5 \%$ & $45,5 \%$ & Ada PE \\
\hline Maja & 6 orang & $19,6 \%$ & $80,4 \%$ & Ada PE \\
\hline Curugbitung & - & - & - & Tidak ada PE \\
\hline Cipanas & 3 orang & $7,5 \%$ & $92,5 \%$ & Ada PE \\
\hline Lebak Gedong & 34 orang & $0 \%$ & $100 \%$ & Ada PE \\
\hline
\end{tabular}

Keterangan:

"Kecamatan Jasinga hanya dilakukan pemeriksaan jentik tanpa pelacakan penderita/tersangka DBD sehingga dikelompokkan tidak ada penyelidikan epidemiologi

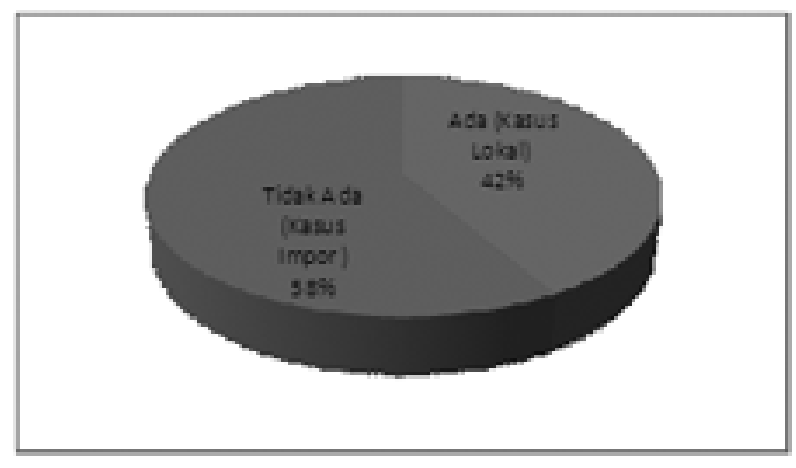

Gambar 1. Distribusi Frekuensi Potensi Penularan Horizontal DBD

pusat pelayanan kesehatan. ${ }^{25}$ Selain itu, tingkat pendidikan penderita yang dinyatakan mampu menerima berbagai informasi yang berhubungan dengan DBD dari media massa elektronik dan cetak serta petugas kesehatan. Semakin tinggi pendidikan seseorang, semakin luas wawasan sehingga meningkatkan pengetahuan.

Hasil penelitian tentang perilaku yang dihubungkan dengan DBD juga ditemukan pada beberapa penelitian lain yang menjelaskan bahwa sebagian besar penderita DBD berperilaku kurang baik dalam melaksanakan kegiatan pencegahan DBD. ${ }^{21} \mathrm{Hal}$ ini kemungkinan besar terjadi karena kesadaran yang kurang terhadap perilaku kesehatan mencegah DBD. Ketidaksesuaian antara pengetahuan dan perilaku kesehatan tersebut menunjukkan pengetahuan baik belum tentu mendorong ke arah perilaku mencegah penularan DBD yang baik. ${ }^{21}$

Temuan tentang TPA sebagai tempat berkembang biak nyamuk Aedes sp. juga ditemukan oleh beberapa penelitian lain. Hal ini menegaskan bahwa sebagian besar penderita DBD memiliki TPA di rumah. Kemungkinan besar nyamuk berkembang biak sebab penduduk di wilayah perdesaan mempunyai kebiasaan menampung air di dalam TPA. Pada wilayah perdesaan yang diteliti, air yang dialirkan melalui pipa-pipa tidak mengalir dengan lancar dan sering terjadi penyumbatan sehingga tidak pernah dibiarkan kosong. Penduduk sengaja menyisakan air bersih untuk keperluan sehari-hari ketika air ledeng mengalami penyumbatan dan berakibat pada TPA yang menjadi tempat perindukan nyamuk Aedes $s p .^{21}$

Lima kasus DBD $(41,7 \%)$ diduga merupakan kasus lokal yang kemungkinan besar mengalami penularan dari sumber lokal di wilayah perdesaan daerah perbatasan Kabupaten Bogor dan Kabupaten Lebak tahun 2012. Hal ini didukung oleh penemuan tempat perindukan dan larva (jentik) Aedes sp. di sekitar tempat tinggal kasus perdesaan. Temuan tentang potensi penularan horizontal atau kasus lokal DBD sesuai dengan penelitian sebelumnya. Meskipun tingkat migrasi penduduk tercatat cukup tinggi, tidak satupun penduduk yang tercatat melakukan perjalanan ke daerah endemis virus dengue. ${ }^{5}$ Hal ini mengindikasikan bahwa kemungkinan besar telah terjadi transmisi penyakit DBD di wilayah perdesaan.

Terdapat empat puskesmas $(57,1 \%)$ yang mampu melakukan kegiatan penyelidikan epidemiologi DBD sesuai prosedur tetap Kementerian Kesehatan Republik Indonesia yang umumnya dilakukan di wilayah perkotaan. Hal tersebut seharusnya dapat dilakukan di wilayah perdesaan daerah perbatasan Kabupaten Bogor dan Kabupaten Lebak pada tahun 2012. Namun, penyelidikan epidemiologi DBD yang dilakukan masih kurang sesuai dengan prosedur Kementerian Kesehatan. Hal ini menunjukkan bahwa kapasitas puskesmas dalam melakukan penyelidikan epidemiologi DBD di wilayah perdesaan harus ditingkatkan. Untuk itu, kemampuan penyelidikan epidemiologi kasus-kasus DBD di wilayah perdesaan harus ditingkatkan, khususnya wilayah "hin- 
terland" di sekitar metropolitan Indonesia. Hal tersebut mendesak untuk dilakukan mengingat wilayah perdesaan tersebut telah ditemukan nyamuk Aedes sp. yang merupakan vektor penularan DBD.

\section{Kesimpulan}

Transmisi horizontal DBD di wilayah perdesaan daerah perbatasan Kabupaten Bogor dan Kabupaten Lebak tahun 2012 kemungkinan besar telah terjadi. Hal ini terbukti dengan ditemukan lima kasus DBD yang diduga merupakan kasus lokal dan hasil penyelidikan epidemiologi DBD menunjukkan bahwa di wilayah perdesaan tersebut terdapat nyamuk Aedes sp. yang merupakan vektor penular DBD. Sebagian besar kasus terjangkit pada orang yang berjenis kelamin laki-laki, berusia $\geq 15$ tahun, tidak bekerja/ibu rumah tangga, melakukan mobilitas, mempunyai pengetahuan yang baik, berperilaku kesehatan kurang baik, dan mempunyai tempat penampungan air. Ditemukan kasus yang diduga merupakan kasus lokal dan belum semua puskesmas mampu melakukan kegiatan penyelidikan epidemiologi DBD.

\section{Saran}

Kapasitas puskesmas perdesaan, khususnya wilayah "hinterland" kota-kota besar harus dipersiapkan dalam hal manajemen DBD mengingat angka kematian DBD yang tinggi $(22 \%)$ dan kemampuan penyelidikan epidemiologi sesuai prosedur tetap penanganan kasus DBD berbasis komunitas yang masih rendah.

\section{Daftar Pustaka}

1. World Health Organization. Dengue and severe dengue. 2012 January [cited 2012 Februari 4]. Available from: http://www.who.int/mediacentre/factsheets/fs117/en.

2. Kittayapong P. Malaria and dengue vector biology and control in Southeast Asia. Mahidol University, Faculty of Science, Center for Vectors and Vector Borne Diseases and Department of Biology; 2005 [cited 2012 Februari 6]. Available from: http://www.library.wur.nl/frontis/disease_vectors/10_kittayapong.pdf.

3. Kumarasamy V, Chua SK, Hassan Z, Wahab AH, Chem YK, Mohamad $\mathrm{M}$, et al. Evaluating the sensitivity of a commercial dengue NS1 antigencapture ELISA for early diagnosis of acute dengue virus infection. Singapore Medical Journal. 2007 [cited 2012 March 5]; 48 (7): 669-73. Available from: http://www.smj.sma.org.sg/4807/4807a12. pdf.

4. Zafar H, Dhodhy M, Hayyat A, Akhtar N, Rizwan F, Chaudhary B, et al. Seroprevalence of dengue viral infection in healthy population residing in rural areas of District Rawalpindi. International Journal of Pathology. 2010 July [cited 2012 January 19]; 8 (1): 13-5. Available from: http://www.jpathology.com/Issues/IJP\%20Vo1\%2081/Seroprevalence $\% 20 \% 20$ of $\% 20 \% 20$ Dengue $\% 20 \% 20$ Viral $\% 20 \%$ 20Infection $\% 20 \% 20$ in $\% 20 \% 20$ Healthy $\% 20 \% 20$ Population $\% 20 \%$ 20residing \%20in\%20Rural\%20Areas.pdf.

5. Mishra R, Kumar P. A study on outbreak of dengue from Bihar, India- establishing new foci, attributable to climatic changes. Journal of Public Health and Epidemiology. 2011 November [cited 2012 January 6]; 3 (11): 489-502. Available from: http://www.academicjournals. org/jphe/PDF/pdf201116\%20November/Mishra\%20et\%20al.pdf.

6. Pusat Data Surveilans dan Epidemiologi Kementerian Kesehatan Republik Indonesia. Demam berdarah dengue di Indonesia tahun 19682009. Buletin Jendela Epidemiologi. 2010 Agustus [diakses tanggal 30 Januari 2012]; 2: 1-14. Diunduh dari: http://www.depkes.go.id/downloads/publikasi/buletin/BULETIN\%20DBD.pdf.

7. Kementerian Kesehatan Republik Indonesia. Kebijaksanaan program P2-DBD dan situasi terkini DBD Indonesia. 2004 Februari [diakses tanggal 21 Agustus 2011]. Diunduh dari: http://www.dinkes-sulsel.go. id/new/images/pdf/buku/kebijakan\%20program\%20dbd.pdf.

8. Achmadi UF. Manajemen demam berdarah berbasis wilayah. Buletin Jend Epidemiologi. 2010; 2: 15-20.

9. Achmadi UF. Manajemen penyakit berbasis wilayah. Jakarta: Penerbit Universitas Indonesia (UI-Press); 2008.

10. Balai Besar Teknik Kesehatan Lingkungan dan Pemberantasan Penyakit Menular. Surveilans penyakit menular dan faktor risiko di daerah perbatasan antarprovinsi. Jakarta: Balai Besar Teknik Kesehatan Lingkungan dan Pemberantasan Penyakit Menular; 2011.

11. Vong S, Khieu V, Glass O, Ly S, Duong V, Huy R, et al. Dengue incidence in urban and rural Cambodia: results from population-based active fever surveillance 2006-2008. PLoS Neglected Tropical Diseases. 2010 November [cited 2012 January 19]; 4 (11): 1-10. Available from: http://www.ncbi.nlm.nih.gov/pmc/articles/PMC/2994922/pdf/pntd.00 00903.pdf.

12. Azami NAM, Salleh SA, Neoh H, Zakaria SZS, Jamal R. Dengue epidemic in Malaysia: not a predominantly urban disease anymore. BioMed Central. 2011 [cited 2012 June 5]; 4 (216): 1-4. Available from: http://www.biomedcentral.com/content/pdf/1756-0500-4-216.pdf

13. Jamaiah I, Rohela M, Nissapatorn V, Maizatulhikma MM, Norazlinda R, Syaheerah $\mathrm{H}$, et al. Prevalence of dengue fever and dengue hemorrhagic fever in Hospital Tengku Ampuan Rahimah, Klang, Selangor, Malaysia. Southeast Asian Journal of Tropical Medicine and Public Health. 2005 [cited 2012 January 4]; 36 (4): 196-201. Available from: http://www. tm.mahidol.ac.th/seameo/2005_36_spp4/36sup4_196.pdf.

14. Khan E, Kisat M, Khan N, Nasir A, Ayub S, Hasan R, et al. Demographic and clinical features of dengue fever in Pakistan from 2003-2007: a retrospective cross-sectional study. PLoS ONE. 2010 September [cited 2012 June 5]; 5 (9): 1-7. Available from: http://www.ukpmc.ac.uk/articles/PMC2938342/pdf/pone.0012505.pdf.

15. Tsuzuki A, Thiem VD, Suzuki M, Yanai H, Matsubayashi T, Yoshida LM, et al. Short report: can daytime use of bed nets not treated with insecticide reduce the risk of dengue hemorrhagic fever among children in Vietnam? American Journal of Tropical Medicine and Hygiene. 2010 [cited 2012 June 10]; 82 (6): 1157-9. Available from: http://www.ajtmh.org/content/82/6/1157.full.pdf.

16. Mohammed H, Ramos M, Armstrong J, Munoz-Jordan J, Arnold-Lewis KO, Ayala A, et al. An outbreak of dengue fever in St. Croix (US Virgin Islands) 2005. PLoS ONE. 2010 October [cited 2012 June 9]; 5 (10): 15. Available from: http://www.ncbi.nlm.nih.gov/pmc/articles /PMC2965679/pdf/pone.0013729.pdf

17. Guha-Sapir D, Schimmer B. Dengue fever: new paradigms for a chang- 
ing epidemiology. BioMed Central. 2005 March [cited 2012 January 6]; 2 (1): 1-10. Available from: http://www.ete-online.com/content/pdf1/ 742-7622-2-1.pdf

18. Hati AK. Studies on dengue and dengue haemorrhagic fever (DHF) in West Bengal State, India. Journal of Communicable Disease. 2006 [cited 2012 January 6]; 38 (2): 124-9. Available from: http://www.ismocd.org/jcd/38_2/s2.pdf

19. Figueiredo MA, Rodrigues LC, Barreto ML, Lima JW, Costa MC, Morato $\mathrm{V}$, et al. Allergies and diabetes as risk factors for dengue hemorrhagic fever: results of a case control study. PLoS Neglected Tropical Disease. 2010 June [cited 2012 june 9]; 4 (6): 1-6. Available from: http://www.ncbi.nlm.nih.gov/pmc/articles/PMC2879373/pdf/ pntd.0000699.pdf.

20. Patumanond J, Tawichasri C, Nopparat S. Dengue hemorrhagic fever, Uttaradit, Thailand. Emerging Infectious Diseases. 2003 October [cited 2012 June 12]; 9 (10): 1348-9. Available from: http://wwwnc.cdc.gov/ eid/article/9/10/pdfs/02-0681.pdf.

21. Nalongsack S, Yoshida Y, Morita S, Sosouphanh K, Sakamoto J. Knowledge, attitude, and practice regarding dengue among people in Pakse, Laos. Nagoya Journal of Medical Science. 2009 [cited 2012 January 27]; 71: 29-37. Available from: http://www.med.nagoya-u.ac.jp
/med/lib/nagoya_j_med_sci/7112/p029-037_Soodsada.pdf.

22. Wichmann O, Mühlberger N, Jelinek T. Dengue: the underestimated risk in travelers. Dengue Bulletin. 2003 [cited 2012 June 6]; 23: 126-37. Available from: http://www.tropnet.net/file/admin/Redakteure/ Dengue_Bulletin_2003.pdf.

23. Itoda I, Masuda G, Suganuma A, Imamura A, Ajisawa A, Yamada K, et al. Clinical features of 62 imported cases of dengue fever in Japan. American Journal of Tropical Medicine and Hygiene. 2006 [cited 2012 June 6]; 75 (3): 470-4. Available from: http://www.ajtmh. org/content/753/470.full.pdf.

24. Gama T, Azizah, Betty RF. Analisis faktor risiko kejadian demam berdarah dengue di Desa Mojosongo Kabupaten Boyolali. Eksplanasi. 2010 Oktober [diakses tanggal 5 Juni 2012]; 5 (2): 1-9. Diunduh dari: http://www.kopertis6.or.id/journal/index.php/eks/article/download/1210.pdf.

25. Pichainarong N, Mongkalangoon N, Kalayanarooj S, Chaveepojnkamjorn W. Relationship between body size and severity of dengue hemorrhagic fever among children aged 0-14 years. Southeast Asian Journal of Tropical Medicine and Public Health. 2006 March [cited 2012 June 9]; 37 (2): 283-8. Available from: http://www.tm. mahidol.ac.th/seameo/2006_37_2/07-3680.pdf. 